\title{
Technology and Early Science Education: Examining Generalist Primary School Teachers' Views on Tacit Knowledge Assessment Tools
}

\author{
Michael Hast ${ }^{1}$ \\ ${ }^{1}$ School of Management and Social Sciences, St Mary’s University, Twickenham, UK \\ Correspondence: Michael Hast, School of Management and Social Sciences, St Mary's University, Twickenham \\ TW1 4SX, UK. Tel: 44-(0)-20-8240-4366. E-mail: michael.hast@stmarys.ac.uk
}

Received: June 4, 2017 Accepted: July 16, $2017 \quad$ Online Published: October 28, 2017

doi:10.5539/ies.v10n11p135

URL: https://doi.org/10.5539/ies.v10n11p135

\begin{abstract}
For some time a central issue has occupied early science education discussions - primary student classroom experiences and the resulting attitudes towards science. This has in part been linked to generalist teachers' own knowledge of science topics and pedagogical confidence. Recent research in cognitive development has examined the role of so-called tacit knowledge and its potential benefits for supporting conceptual development in children. However, the incorporation of such tools would depend on teachers' willingness to use it. Taking a qualitative approach through interviews, the present study examined 12 generalist primary school teachers' views on science education and their perceptions of tacit knowledge assessment as an approach to facilitating conceptual change. The overall results indicate positive attitudes embedded within a model centred on trust and responsibility of learning. These findings support the use of relevant software for teaching children by emphasising the willingness of teachers to use such technology, which has further consequences for continuing professional development of classroom teachers who do not have formal science backgrounds, which in turn should promote science achievements among students.
\end{abstract}

Keywords: generalist primary teachers, tacit knowledge assessment, technology, CPD

\section{Introduction}

Science in the primary classroom is seen as an important key for children to understand the world around them and is thus regarded as an essential component of early classroom education (Alexander, 2010). Future economies will increasingly rely on a workforce that is science and technology literate (Wellcome Trust, 2014). Targeting science at the primary education stage is pivotal given that by the age of 14 students have developed interest in and attitudes towards science in schools (DeWitt, Archer, \& Osborne, 2014; Osborne \& Dillon, 2008) but leading up to this, positive attitudes towards science decline with age and this decline starts from as early as 7 years of age (Said, Summers, Abd-El-Khalick, \& Wang, 2016). Recent findings from various international assessments such as PISA (Kjærnsli \& Lie, 2011) and TIMSS (Martin, Mullis, Foy, \& Hooper, 2016) demonstrate that there is a generally low tendency for primary school children in the UK to engage with science, both during their education and in terms of future career aspirations. To develop a more literate population and to avoid issues of declining interest in science, young people need to continue learning science and therefore need to be given the opportunity to develop such interests as early as possible

According to the most recent TIMSS evaluation fewer than half of primary school children in England reached a high or advanced benchmark for science at the fourth grade level (Martin et al., 2016). Various explanations can be offered as to why this might be the case. First, a key element contributing to the lack of engagement seems to be the issue of knowledge of and attitudes towards science (Jenkins \& Nelson, 2005). Children enter formal education with a wide range of conceptions relating to science, such as the commonly held view that objects fall faster than others because they are heavier (Hast \& Howe, 2012, 2013; for a more comprehensive overview of misconceptions in primary science see e.g. Allen, 2014). In the classroom they are frequently incommensurate with accepted scientific views and with the concepts that are, as a result, taught. Most problematically they are often found to be highly resistant to change through instruction, affecting subsequent learning of related concepts (Duit, Treagust, \& Widodo, 2013; Eriyilmaz, 2002; Gomez-Zwiep, 2008; Pine, Messer, \& St John, 2001; Trend, 
2001). These initial conceptions are often the result of extensive everyday world experiences (Bliss, 2008; Eshach, 2007; Klaassen, 2005) and it is precisely such early life-world experiences that seem to act as major factor in the choice to pursue science education at later points (DeWitt et al., 2013). This is not surprising given that if initial science education is not successful in its engagement then advanced concept development cannot thrive due to a lack of a stable conceptual knowledge base (Wiser \& Smith, 2008).

Understanding children's conceptions is crucial for educational practice, as any prior knowledge needs to be considered so that successful instructional approaches can be designed, particularly in the early years of education (Duschl, Schweingruber, \& Shouse, 2006). Recent research has turned towards so-called tacit knowledge of scientific conceptions. Such knowledge differs from explicitly stated understanding (which can be expressed verbally, in writing etc.) in that it taps underlying knowledge structures that are set to provide quick responses without conscious awareness but elicit feelings of familiarity (Collins, 2010; Polanyi, 1967). In the context of scientific conceptions the work collectively shows that children may hold explicitly stated ideas about object motion that are incommensurate with accepted scientific views such as that heavy objects always fall faster than lighter objects and that lighter objects roll faster along even surfaces than heavier ones (Hast \& Howe, 2012, 2013). However, these same children appear to hold underlying tacit knowledge about relevant events that indicates a more accurate representation of such scientific concepts but that does not appear in their verbalised theories (Hast \& Howe, 2015, 2017; Howe, Taylor-Tavares, \& Devine, 2012, 2014; also see Hast, 2014; Howe, 2014). Tacit knowledge has consequences for science education - 'a great deal of our commonsense knowledge, and there is a large amount of it, is tacit' (Bliss, 2008, p. 123; also see Brock, 2015). Indeed it has already been made use of in the development of intervention approaches to facilitate conceptual change in children; children who were given the opportunity to engage with software that taps tacit knowledge about falling objects showed much greater score improvements from pre- to post-test than children who did not get to work with the computer program (Howe, Devine, \& Taylor-Tavares, 2013; Howe, Taylor-Tavares, \& Devine, 2016). Harnessing such opportunities to enable conceptual change is critical to promote an understanding of and resulting interest in science. Classroom teachers are the key to providing children with access to such a learning opportunity.

A prime factor that may either be actively contributing to student attitudes or at least inhibit an overcoming of such negative views appears to arise from the fact that many generalist primary school teachers lack sufficient training in science knowledge, particularly physical science (Avraamidou, 2015; Davis, Petish, \& Smithey, 2006). To-date, pre-service teachers in England and Wales undergoing postgraduate training are required to complete and pass skills tests in numeracy and literacy (Department for Education, 2015). However, there is no such requirement for any other subject areas, including science. In fact, generalist primary school teachers do not require any science qualifications beyond GCSE level - aged 16 years - in order to teach (Wellcome Trust, 2014). In fact, only around one third of primary school teachers in England have formal science qualifications beyond this level and pupil achievement is lower where teachers lack such qualifications (Martin et al., 2016). Additional research indicates a critical relationship between scientific literacy levels among teachers and their attitudes towards science - the lower the literacy level the more negative the attitudes (Murphy \& Beggs, 2005; Rice, 2005; Van Aalderen-Smeets, Walma van der Molen, \& Asma, 2012). This reluctance further impacts on the confidence to successfully teach science and to be able to incorporate new teaching content (Avraamidou, 2013, 2014; Howitt, 2007; Pedretti Bencze, Hewitt, Romkey, \& Jivraj, 2008).

Issues around knowledge and confidence seem particularly elevated when it comes to teaching physical science in relation to other areas of science, and primary school teachers are less likely to view themselves as being very well prepared to teach this (Avraamidou, 2015; Martin et al., 2016). Object motion in particular plays a special role in science. It is a ubiquitous concept which we engage with from birth onwards and witness on a daily basis in multiple situations. It has implications for development of motor skills and using these to judge events and plan actions (White, 2012). Within more formal contexts it represents a basis for many higher-level elements of physics, such as force, energy and relativity (Shankar, 2014). As such it has a significant impact on successful engagement with science education. However, despite its significance for education the limitations in teachers' confidence, subject knowledge and understanding of young children's learning in science continue to act as key barrier in promoting educational achievement (Glauert, Compton, \& Manches, 2012).

Additionally, the use of technology in teaching is no new phenomenon; research has shown that using computer games can enhance learning and participation in technology-enhanced activities leads to higher intrinsic motivation (Tüzün, Yılmaz-Soylu, Karakuş, İnal, \& Kızılkaya, 2009) - essential to heightening interest in science. The most recent TIMSS evaluation (Martin et al., 2016) showed that three in four primary school children in England had technology available to supplement their learning of science. However, when it came to using it for scientific experimentation and studying simulations this number was significantly reduced, with only 
half of science teaching involving technology. There is some indication that primary school teachers do have positive attitudes towards using information and communication technology (ICT) in their teaching of science (Cavas, Cavas, Karaoglan, \& Kisla, 2009) and that teachers value ICT as a tool for pupil learning and differentiation (Smeets, 2005). However, others suggest that this group of teachers-and those arriving into the profession-actually lack appropriate technological literacy (van Aalderen-Smeets et al., 2012) despite many of these teachers now being considered as part of the so-called digital natives (Prensky, 2012). Moreover, technology is significantly underused in science education, with the key issue appearing to be lack of access to appropriate resources (Bingimlas, 2009; Dawson, 2008).

A key tool in attempting to resolve these issues for generalist teachers in particular would be through continuing professional development (CPD), both at the science and the technology level (Tondeur et al., 2012). Yet challenges are encountered here, too. A recent report by the Wellcome Trust (2014), for instance, indicates that provision of such opportunities to improve primary science education in England remains problematic. Despite being a core part of the National Curriculum, school leadership does not give science the levels of priority accorded to literacy and numeracy, due to differences in accountability, and there is insufficient access to science expertise within schools for generalist classroom teachers. The same report emphasises that while science leadership is still prioritised, generalist classroom teachers also need to engage with CPD to enhance pupils' experiences of science in the primary school classroom and to directly share the gained expertise with children in the classroom rather than follow a cascaded training approach. By targeting generalist teachers there is a better opportunity to target limitations in their own scientific knowledge, how children develop such knowledge and therefore how to approach lesson planning (see similar recommendations made over various years by the Office for Standards in Education, Children's Services and Skills, 2008, 2011, 2013).

Successful implementation of tacit knowledge assessment tools largely depends on teachers being able and willing to incorporate it into their classroom teaching. By combining the various issues presented so far, the present study seeks to examine whether tacit knowledge assessment tools do not just provide learning advantages for children but whether generalist teachers who lack knowledge and confidence in teaching elementary science as well as using technology to support science teaching feel it can serve as a teaching tool. Moreover, understanding teacher attitudes towards science teaching and technology as well as their recognition of own limitations may have important consequences for the development of CPD for generalist classroom teachers that might potentially include tacit knowledge assessment. This was addressed through an examination of teacher views on science education, children's roles and the perceived potential of using tacit knowledge assessment tools in teaching.

\section{Method}

\subsection{Participants}

Participants were recruited from state primary schools in the Greater London area. Schools were emailed with invitations to take part in research and interested teachers responded. Their suitability to contribute was evaluated based on training background and teaching experience. As this study was primarily concerned with teachers who did not have extensive formal training in science or science education, only teachers who had no formal science education beyond GCSE level (age 16 years) were considered. Another criterion that was considered relevant was teaching experience for teachers in Key Stage 1 (ages 5-7 years). The software is concerned with specific aspects of physical science that are currently only taught in Key Stage 2 (ages 8-11 years; Department for Education, 2013) but some elements had been part of the Key Stage 1 science curriculum prior to the establishment of the new curriculum (cf. Department for Education and Employment, 1999). Therefore Key Stage 1 teachers were only considered for the research if they had taught relevant physical science topics prior to the installment of the new curriculum in September 2014. Level of ICT experience was not specified but teachers were invited on the basis of a self-perceived lack of confidence in and experience of teaching using technology. A total sample of 12 teachers was selected. Of these, 9 were female and 3 were male. This is an approximate reflection of the gender distribution among the relevant primary school teacher population at the time of data collection (cf. Department for Education, 2016). Because of the content of the current National Curriculum a slightly greater emphasis was placed on Key Stage 2 teachers. As a result, the Key Stage 1 sub-sample was made up of 3 females and 1 male (all teaching Year 2); the Key Stage 2 sub-sample was made up of 6 females and 2 males (across Years 3-6).

\subsection{Procedure}

In order to gain insight into teacher views on science education and their perceptions of tacit knowledge assessment, semi-structured interviews were conducted. The semi-structured interviews were split into four main 
sections. The first section's purpose was to collect background information on the teachers in relation to teacher training and general teaching experience. The second section was about their perceptions of science as a discipline and their attitudes towards teaching science. The third section covered their understanding of scientific knowledge children bring into the classroom. The final section of the interview addressed their views on software assessing tacit knowledge. As part of the final interview section teachers were given the opportunity to engage with the software used in Howe et al. $(2013,2016)$, with minimal guidance from the interviewer (Note 1). Interviews were carried out in teacher classrooms outside of teaching hours. They lasted approximately 45 minutes to 1 hour.

\subsection{Data Analysis}

After completion of interviews these were analysed by drawing on a grounded theory approach (Charmaz, 2014; Corbin \& Strauss, 2014). Transcripts were coded using the three stages of open, axial and selective coding. An initial process of manual line-by-line open coding was performed. This meant reading and re-reading the transcripts whilst identifying all emerging instances of attitudes, feelings, ideas, thoughts and experiences which were repeated multiple times. These were constantly compared both within and across participant transcripts. This was done until theoretical saturation had been reached, that is, until no further new codes emerged from the data. Memos were written alongside the extraction of codes. During the second stage of axial coding the initial codes were then grouped to form thematic relationships with more elaborate definitions based on the memos. Finally, through selective coding central and peripheral themes were identified and relationships between themes were established. Two themes were identified as being at the core of the relational model; 'responsibility' and 'trust'. Any other key themes identified were seen to stand in some relation to this core.

\section{Results and Discussion}

Understanding the value that primary school teachers place on science education was seen as a foundational element when trying to examine the potential of incorporating software. Across the board teachers noted that science education was an important component of the classroom experience, including that it offered opportunities for skills that they could either not gain in other ways or that they could apply across the curriculum:

"The importance is for them to understand the world in which they're living, and I think everything that the children ask, a lot of what the children ask in terms of questioning, there's always a science link to it." (WR)

Teachers also viewed science as a particular curriculum area where children are not afraid of making mistakes, which the teachers felt would lead to more engagement on the children's side:

'In literacy they're quite scared of making mistakes whereas in science, when their bulb blew up because they used too much battery power they were, you know, quite happy with that and wanted to give it another go." ( $A G)$

Teachers are evidently in agreement with Alexander's (2010) view that science is essential for primary education. Understanding the value attached to science education is crucial as such views can impact motivation to teach by considering the goals for completing tasks and feelings or emotional reactions towards these tasks (cf. Thoonen, Sleegers, Oort, Peetsma, \& Geijsel, 2011). By emphasising the value of science education teachers may be signalling openness towards the incorporation of additional teaching approaches and CPD.

All of the teachers rated their confidence in teaching science as a 6 or 7 out of 10 or equivalent, and all of them considered this to be a lower confidence level than for any of their other teaching. Despite similar rating levels the teachers did differ in their perceptions of science. Some viewed it very positively, despite the lack of training background.

"I love science. I don't really understand it very well but I do, I really enjoy it." (RB)

Others saw the fault for not being so confident within themselves. This included the fact that their interests typically lay in fields other than the physical science aspect of the curriculum, but mostly centred on a lack of appropriate knowledge:

"I am interested in science, but I, I'm more interested in the arts and history ... But the more that I do with the children, the more, you know, you have to do wider reading ... I have an interest there, but definitely also have a lack of knowledge." (MS)

This is certainly reflective of the literature, supporting the views that generalist teachers frequently lack knowledge and skills when it comes to science teaching (Avraamidou, 2013, 2014, 2015; Howitt, 2007; Pedretti 
et al., 2008; Murphy \& Beggs, 2005; Rice, 2005; Van Aalderen-Smeets et al., 2012). It is encouraging to see, though, that teachers are able to recognise this as it may contribute towards a stronger willingness to engage with such issues. A third component identified the lack of confidence as being, at least in part, due to a perceived lack of appropriate external support when it comes to trying to think about how to teach physical science in the classroom:

"If I've ever had any CPD in terms of subject areas, it has always been on the English or the maths and reading as opposed to science ... it's funny, because it's a core subject as well, and I just feel... there's never as much emphasis on it." (FL)

Indeed, in the UK primary school science does not receive the same attention as mathematics or literacy. For teachers this experience starts as early as applying for teacher training programmes when they are expected to pass professional skills tests in both subjects prior to taking up their training but are not required to do so for science (Department for Education, 2015) - although science can be seen as a combination of numeracy and literacy skills. However, this may not necessarily be explicitly evident to teachers and could therefore impact on the perceived value of science as a key area of the primary school curriculum (also see e.g. Rogers, 2012).

The particular problem how teaching approaches are influenced by subjective attitudes towards science was identified at various levels. Some teachers felt that their teaching practice was possibly undermined by negative views or lack of understanding whereas others showed clear signs of trying to actively avoid teaching these topics:

"It definitely impacts my own enthusiasm, so if there is a topic that I'm particularly passionate about it shows, but sometimes I'm confused ... if there's something that I don't, I'm not very confident in, we either do a limited amount of time on it or they could just tell that I don't enjoy it very much." (RB)

Nonetheless teachers were equally aware of the consequences that such attitudes might have, recognising that their approaches impact the classroom experiences of the children:

"They don't enjoy it as much. They don't learn half as much that they probably could or should and I probably wouldn't allow them to take as many risks in their learning of it ... because if I've got that kind of barrier I only know so much and so we can't go any further than that." (LT)

This is critical since the literature indicates a relationship between teacher knowledge and student engagement (Martin et al., 2016) as well as impacting on attitudes to teaching, which in turn again interfere with classroom experiences (Avraamidou, 2013, 2014; Howitt, 2007; Murphy \& Beggs, 2005; Pedretti et al., 2008; Rice, 2005; Van Aalderen-Smeets et al., 2012). Nonetheless, like recognition of values of science education, being aware of shortcomings and how they impact classroom experiences may signalise openness towards engaging with alternative teaching approaches that reduce the need for teacher knowledge.

Given the self-identified relative lack of confidence in teaching science it is not particularly surprising that teachers who lack necessary knowledge and insight are prepared to seek advice and support elsewhere. The sources of support can be separated into two camps. Primarily, teachers explained that they tended to seek support from their more experienced colleagues, typically the school's science coordinator:

"We would've had an input from the science coordinator in terms of this is how I would approach a lesson in this, and this is how I'd deal with any misconceptions that might exist, but nothing exterior." $(A G)$

In the other camp are those teachers who, despite some issues with confidence in teaching primary science, took it upon themselves to seek out resources that would support their activity planning, though even here occasionally indicating lack of confidence, expressed through an uncertainty regarding availability of resources. Nonetheless many teachers also referred to various online resources that they used to support their teaching, including making use of simulations and watching videos where experts in their fields discuss science topics, often in more lay terms:

"Often I use short video clips that have explanations on obviously their field, they're going to be much more accurate than, you know, something that I'm less competent on." (CT)

In addition, teachers typically explained that they like teaching science because it is an opportunity for the children to be practical and try out things for themselves. However, they were very aware that this is not always possible in a classroom setting, mostly due to safety issues, and they were then more likely to turn to online demonstrations as a supportive teaching tool:

"So there was one where we were doing on changing states ... different types of metals that you can 
melt, something like that, but you can't do that in class, and so there was a virtual experiment and they could set it up to have them put the metal on the plate and then heat it up and it would measure how long it took to melt." (FL)

This suggests that there are realistic expectations among teachers about what can and cannot be achieved in the science classroom, and that alternatives have to be considered. Not only does this enable teachers to turn towards experts in their fields, it also highlights the recognition of the value of using simulations in science teaching that is reflected in the literature (Hennessy, 2006; Hennessy et al., 2007; Rutten, van der Veen, \& van Joolingen, 2015).

A key factor emerging from the interviews was that teachers recognised the importance of including the children in the process of teaching and learning. This recognition has had an impact on how the teachers engage with addressing own knowledge and teaching methods, especially if it is an area towards which they might not have particularly positive attitudes:

"Perhaps I wouldn't have built pirate ships with them if I hadn't realised that actually they were so enthused in this, and ... we only brought in our space topic just because they would not stop talking about space." (RB)

This affords a shift of responsibility onto the children, or a more strongly coordinated process between children and teachers. This coordination can lead to higher levels of motivation in student learning (cf. Reeve, 2006) and strengthens self-determination (Deci \& Ryan, 2012, 2013). Deci and Ryan point out that based on a constant active exchange with the classroom environment, supportive resources are needed to nurture inner motivational resources; action and development come from within - an idea akin to self-collaboration (Hast, 2014). Howe et al.'s $(2013,2016)$ software allows for this as in using it the teacher merely acts as facilitator and the student takes on more of the instruction process. This also provides teachers with the opportunity to become more self-determined in their teaching, which in turn can lead to self-determined student learning (Roth, Assor, Kanat-Maymon, \& Kaplan, 2007).

The teachers were quite able to identify children's limited understanding, including being able to give specific examples (cf. Gomez-Zwiep, 2008; Pine et al., 2001), despite finding it a challenge at times:

"We made rocket balloons once to test friction, so we had straws that were going over a piece of wool, a piece of string, a piece of wire, and to see which had, you know, which was going to slow down and why it was going to slow down, and a lot of children, they were, you know, straight up said "oh no, that's definitely going to slow down," just from their understanding, I suppose, of what they would have done in terms of informal learning ... playing with cars or using, you know, matting as opposed to something smoother." (MS)

The key source of misconceptions was recognised to come from external learning opportunities, including informal learning settings, but mostly simply from experiencing the everyday world around them:

"From the books that they read at home and the programs that they watch, from when they've been to the zoo or been on holiday." (WR)

Much of children's knowledge is indeed acquired through extensive experiences with the everyday world and within contexts where parents or older siblings are involved, too (Bliss, 2008; Eshach, 2007; Klaassen, 2005). This naturally posed a challenge for teachers:

"Identifying them ... the children won't necessarily come and say to you, 'I think this, 'straight off, and you might find it halfway through something, and then that means you need to adapt what you're doing in the middle of your teaching in order to address that." (CS)

In addition, teachers recognised the challenges they faced in their instruction as many ideas in science can be highly resistant to change:

"One child was absolutely adamant that plasticine would sink straight to the bottom and obviously we were saying that, you know, sometimes it will sink and sometimes it won't ... the children were sort of debating it, saying 'no, I've done that at home, when you make it flat and it has a lot of surface area, then it will float'." (RB)

Most importantly, the teachers were able to examine where they thought the children's knowledge had come from. Interestingly, one teacher already made reference to scientific conceptions that can be seen as being reflective of underlying knowledge as assessed through the software, which indicates awareness that the surface knowledge displayed by children is not always definitive: 
"It is there but you need to dig a little deeper for it to become evident to them." (MS)

Once again this awareness highlights opportunities for having children engage with tacit knowledge assessment approaches since the software helps children challenge their own ideas through self-collaboration (cf. Hast, 2014).

A key element emerging in the interviews was the issue of children's trust and how that interfered with facilitating conceptual change through teaching. Some of the teachers were optimistic about how readily children appeared to accept their insight:

"I think children are very accepting at this age of their, of their teachers if you tell them something.

That's why you have to be so careful; they really take it on board." (LT)

Other teachers, on the other hand, pointed out that children needed more convincing when trying to address their scientific viewpoints:

"You often have to prove things to them." (MS)

In trying to examine why this might be the case several teachers mentioned that they felt children's ideas most likely existed because of close authority figures such as parents, who are highly trusted, and the teachers recognised this as a barrier to their own teaching towards overcoming misconceptions:

"I think it's very difficult when they've got an idea in their heads to then mould a new one ... from my experience at least, they found it very difficult to change their view, particularly if it's been a parent or somebody that says 'oh, it's like this' and actually it isn't like that and the parent's made a mistake." $(R B)$

Most of the teachers, however, identified children's self-trust as being central to resistance in changing conceptions. These views seem to be based on the notion of personal testimony:

"If they've seen something or observed something then it must be true cause they've seen it." (CT)

There is an interesting mix in perceptions here. Indeed, the literature suggests that trust is an important aspect in the construction of scientific knowledge throughout childhood, highlighting in particular the element of self-generated knowledge versus the testimony of others. Of particular interest is the shift from a default bias to rely on testimony towards developing robust self-generated theories (Jaswal, 2010; Jaswal \& Pérez-Edgar, 2014; Tamis-LeMonda et al., 2008) and resistance to misleading testimony (Jaswal et al., 2014). This robustness may even present itself when confronted with real-life evidence demonstrations that are to the contrary of own established ideas (cf. Baker, Murray, \& Hood, 2009). Yet this confidence in own knowledge, including in the domain of science (Howe, 2014; Jaswal, 2013), should not simply be seen as resistance than cannot be overcome but as a key teaching tool that can be used to foster self-collaboration in knowledge formation (Hast, 2014) something the software in question sets out to achieve.

A further component to evaluate is the aspect of responsibility of learning new scientific knowledge. Addressing how teachers deal with the shortcomings in their own knowledge and confidence in teaching physical science in the event of not possessing the answer themselves some did recognise the need to be more proactive and to further their own knowledge. It was very clear, however, that the majority of teachers believed in shifting the responsibility of learning onto the children by encouraging a process of self-teaching. This occurred by giving the children more ownership over their learning experiences, either on an individual or on a group level:

"I'm always very honest, I say, you know, sometimes I don't know the answer and that we need to find out, or perhaps that could be something you could do at home, you could find that out and bring the answer in the next day." (RS)

Teacher questioning is a prominent feature of classroom dialogue, and within this process the responsibility of thinking remains with the student (Chin, 2006; van Zee, Iwasyk, Kurose, Simpson, \& Wild, 2001). There is discussion within the literature that examines the issue of ownership in science education, including in relation to virtual experiments (e.g. Childers \& Jones, 2015; O’Neill \& Barton, 2005). Virtual experimentation provides students with control which is seen as crucial for engagement with topics and the resulting learning process. Students become their own teachers, and the classroom teachers in turn become outsiders for the duration of the experimentation. This aspect of ownership provides more positive views on science. The teacher remains as a facilitator but is able to shift responsibility of the learning and teaching process onto the children, making science education both child-directed and child-led - again emphasising the beneficial aspect of self-collaboration (Hast, 2014) that the underlying knowledge assessment approach supports.

Importantly, the software was demonstrated and evaluated only after insight was gained into the teachers' values 
and perceptions. This means the views presented above can be seen as not being influenced by this particular computer program, strengthening the relevant validity of the discussed ideas. Views on how the software impacted their own conceptions were mixed. Some felt that their own ideas had not been challenged, but most did feel that the software prompted them to reconsider their own ideas:

"I learnt that I was wrong on some things ... probably my knowledge changed; I couldn't necessarily explain it though." (RB)

This insight seems to match small-scale unpublished research with adults using the same software (cf. University of Cambridge, 2017) suggesting that adults too can benefit from working with the intervention programme. This has implications for teachers and could indicate the additional potential for using the software as a professional development tool. As far as the benefits for children's learning were considered, teachers were very positive in their evaluations of the software. Teachers commented on the overall ease of access, including how it helps to account for different computer skills without disadvantaging any students. More importantly, they saw immediate benefits in the opportunity to provide children with opportunities to reflect on their reasoning:

"I like the fact that it replays and gives you that choice to see both against each other again, so you can, the idea of mulling it over and trying, trying it again and again, rather than just accepting it once at face value." (FL)

Nonetheless the teachers also provided feedback that would be worthwhile considering in trying to develop a more successful conceptual intervention programme. Most of these comments were more about the presentation of the software, including fonts perhaps being too difficult for the younger children to read. However, they also raised potential issues with some of the content phrasing, much akin to common critiques of Piagetian research, particularly for the younger children (see e.g. Baucal, Arcidiacono, \& Budjevac, 2013):

"When it says 'do you think your answer is correct' in most children's eyes that would only make them think 'oh, I'm wrong, so I have to say no'." (CT)

Some teachers recognised the software as a useful differentiation tool for their teaching activities:

"I could use it to find out what they do and don't understand and then could potentially differentiate based on that cause I don't differentiate in science at the moment." (RB)

However, from the differentiation viewpoint other teachers were more sceptical as to how effective implementing the software really would be in practice, both from a practical aspect and how the software might be perceived by the children:

"A lot of the time the weaker children go off to use apps and programs on the computer and so the ones that think that they're brighter would have the idea that this is for maybe some lower level children because that's what they normally do, because they need this support ... there's potential that they may have a slightly negative attitude towards it." (MO)

Beyond suggestions based on their own experiences where they seek advice, such as STEM, teachers felt some form of personal interaction would be the most useful approach in trying to raise awareness of the software. Some suggested school-internal contact points as a key reference:

"Through the science coordinators of schools and then, like, the potential of doing a staff meeting on it, so if there were resources for the science coordinator, like a PowerPoint about what it is, the purpose of it and how to use it in class, that would make it much more likely that they would then deliver a staff meeting on this. " (FL)

However, teachers were equally welcoming of external input in demonstrating the software, including academic researchers. Teachers expressed themselves positively about this aspect as it removed some of their own burden in finding resources and figuring out how to use them:

"We had [company name] who came to speak to us and they showed us exactly how to use the program and how the children would use that in class ... that was good ... As a teacher, it just, you can be a bit passive and you don't have to be doing it proactively all the time." (LT)

This is something also envisaged by the Department for Education (2010), promoting the view that academics and professionals within education need to establish a closer relationship in order to reap further benefits on both sides. The academic research equally supports this standpoint (Vanderlinde \& van Braak, 2010). Collectively, this indicates a willingness to engage with CPD and provides an opportunity to structure relevant activities for generalist teachers. This again reflects the need for such training for this particular group (Office for Standards in Education, Children's Services and Skills, 2008, 2011, 2013; Tondeur et al., 2012; Wellcome Trust, 2014). 


\section{Conclusion}

From this qualitative evaluation of teachers' insight arises the ability to complement the usefulness of tacit knowledge assessment for children's conceptual development in science. In particular, the software appears to encapsulate all key areas identified through the teacher data. It has become clear that from the teacher perspective the key issues to address towards successful implementation of the software within teaching practice are those of children's trust and responsibility of learning as these appear to impact on teachers' views of their students and the ways in which to facilitate their development. The research discussed here also highlights the benefits of tacit knowledge assessment for a particular type of teacher - relatively inexperienced and with a lack of training in science and technology. Future research would do well to take into account quantitative measures around motivation and values and how these impact on perceptions of the software as well as exploring in more detail the issue of the central model elements from the child perspective. Overall, despite some identified shortcomings of the software when asked whether they would make use of it, after having tried it out for themselves, the teachers were all very welcoming of the opportunity, providing green light for the development of CPD targeted at generalist teachers:

"Would I use it? Yeah, I would." (MS)

\section{References}

Alexander, R. J. (2010). Children, their world, their education: Final report of the Cambridge Primary Review. London: Routledge.

Allen, M. (2014). Misconceptions in primary science. Maidenhead: Open University Press.

Avraamidou, L. (2013). Prospective elementary teachers' science teaching orientations and experiences that impacted their development. International Journal of Science Education, 35, 1698-1724. http://doi.org/10.1080/09500693.2012.708945

Avraamidou, L. (2014). Studying science teacher identity: Current insights and future research directions. Studies in Science Education, 50, 145-179. http://doi.org/10.1080/03057267.2014.937171

Avraamidou, L. (2015). Reconceptualizing elementary teacher preparation: A case for informal science education. International Journal of Science Education, 37, 108-135. http://doi.org/10.1080/09500693.2014.969358

Baker, S. T., Murray, K., \& Hood, B. M. (2009). Children's expectations about weight and speed in falling objects: The younger the judge, the better? Poster presented at the biennial meeting of the SRCD, Denver, CO.

Baucal, A., Arcidiacono, F., \& Budjevac, N. (2013). "Is there an equal (amount of) juice?" Exploring the repeated question effect in conservation through conversation. European Journal of Psychology of Education, 28, 475-495. http://doi.org/10.1007/s10212-012-0124-7

Bingimlas, K. A. (2009). Barriers to the successful integration of ICT in teaching and learning environments: A review of the literature. Eurasia Journal of Mathematics, Science \& Technology Education, 5, 235-245.

Bliss, J. (2008). Commonsense reasoning about the physical world. Studies in Science Education, 44, 123-155. http://doi.org/10.1080/03057260802264149

Brock, R. (2015). Intuition and insight: Two concepts that illuminate the tacit in science education. Studies in Science Education, 51, 127-167. http://doi.org/10.1080/03057267.2015.1049843

Cavas, B., Cavas, P., Karaoglan, B., \& Kisla, T. (2009). A study on science teachers' attitudes toward information and communication technologies in Education. The Turkish Online Journal of Educational Technology, 8(2), Article 2.

Charmaz, K. (2014). Constructing grounded theory. London: SAGE Publications.

Childers, G., \& Jones, M. G. (2015). Students as virtual scientists: An exploration of students' and teachers' perceived realness of a remote electron microscopy investigation. International Journal of Science Education, 37, 2433-2452. http://doi.org/10.1080/09500693.2015.1082043

Chin, C. (2006). Classroom interaction in science: Teacher questioning and feedback to students' responses. International Journal of Science Education, 28, 1315-1346. http://doi.org/10.1080/09500690600621100

Collins, H. (2010). Tacit and explicit knowledge. Chicago, IL: University of Chicago Press.

Corbin, J., \& Strauss, A. (2014). Basics of qualitative research: Techniques and procedures for developing grounded theory (4th ed.). London: SAGE Publications. 
Davis, E. A., Petish, D., \& Smithey, J. (2006). Challenges new science teachers face. Review of Educational Research, 76, 607-651. http://doi.org/10.3102/00346543076004607

Dawson, V. (2008). Use of information communication technology by early career science teachers in Western Australia. International Journal of Science Education, 30, 203-219. http://doi.org/10.1080/09500690601175551

Deci, E. L., \& Ryan, R. M. (2012). Self-determination theory. In P. A. M. Van Lange, A. W. Kruglanski \& E. T. Higgins (Eds.), The handbook of theories of social psychology: Volume 1 (pp. 416-433). London: SAGE.

Deci, E. L., \& Ryan, R. M. (2013). Handbook of self-determination research. Rochester, NY: University of Rochester Press.

Department for Education. (2010). The importance of teaching. London: DfE.

Department for Education. (2013). National curriculum in England: Science programmes of study - key stages 1 and 2. London: DfE.

Department for Education. (2016). School Workforce in England: November 2016. Retrieved May 20, 2017, from http://www.gov.uk/government/uploads/system/uploads/attachment_data/file/533618/SFR21_2016_ MainText.pdf

Department for Education. (2017). Professional skills tests. Retrieved March 21, 2017, from http://sta.education.gov.uk/

Department for Education and Employment. (1999). The national curriculum for England: Science. London: HMSO.

DeWitt, J., Archer, L., \& Osborne, J. (2014). Science-related aspirations across the primary-secondary divide: Evidence from two surveys in England. International Journal of Science Education, 36, 1609-1629. $\mathrm{http}: / /$ doi.org/10.1080/09500693.2013.871659

DeWitt, J., Osborne, J., Archer, L., Dillon, J., Willis, B., \& Wong, B. (2013). Young children's aspirations in science: The unequivocal, the uncertain and the unthinkable. International Journal of Science Education, 35, 1037-1063. http://doi.org/10.1080/09500693.2011.608197

Duit, R., Treagust, D. F., \& Widodo, A. (2013). Teaching science for conceptual change: Theory and practice. In S. Vosniadou (Ed.), International handbook of research on conceptual change (pp. 487-503). London: Routledge.

Duschl, R. A., Schweingruber, H. A., \& Shouse, A. W. (2006). Taking science to school: Learning and teaching science in grades $K-8$. Washington, DC: The National Academies Press.

Eryilmaz, A. (2002). Effects of conceptual assignments and conceptual change discussions on students' misconceptions and achievement regarding force and motion. Journal of Research in Science Teaching, 39, 1001-1015. http://doi.org/10.1002/tea.10054

Eshach, H. (2007). Bridging in-school and out-of-school learning: Formal, non-formal, and informal education. Journal of Science Education and Technology, 16, 171-190. http://doi.org/10.1007/s10956-006-9027-1

Glauert, E., Compton, A., \& Manches, A. (2012). Creative little scientists: Enabling creativity through science and mathematics in preschool and first years of primary education. Retrieved March 04, 2017, from http://www.creative-little-scientists.eu/sites/default/files/10_3_2-NationalReport_UK_England.pdf

Gomez-Zwiep, S. (2008). Elementary teachers' understanding of students' science misconceptions: Implications for practice and teacher education. Journal of Science Teacher Education, 19, 437-454. http://doi.org/10.1007/s10972-008-9102-y

Hast, M. (2014). Collaborating with the 'more capable' self: Achieving conceptual change in early science education through underlying knowledge structures. ReflectED, St Mary's Journal of Education, 3, 18-25.

Hast, M., \& Howe, C. (2012). Understanding the beliefs informing children's commonsense theories of motion: The role of everyday object variables in dynamic event predictions. Research in Science \& Technological Education, 30, 3-15. http://doi.org/10.1080/02635143.2011.653876

Hast, M., \& Howe, C. (2013). Towards a complete commonsense theory of motion: The interaction of dimensions in children's predictions of natural object motion. International Journal of Science Education, 35, 1649-1662. http://doi.org/10.1080/09500693.2011.604685

Hast, M., \& Howe, C. (2015). Children's predictions and recognition of fall: The role of object mass. Cognitive 
Development, 36, 103-110. http://doi.org/10.1016/j.cogdev.2015.10.002

Hast, M., \& Howe, C. (2017). Changing predictions, stable recognition: Children's representations of downward incline motion. British Journal of Developmental Psychology. Advance online publication. http://doi.org/10.1111/bjdp.12191

Hennessy, S. (2006). Integrating technology into teaching and learning of school science: A situated perspective on pedagogical issues in research. Studies in Science Education, 42, 1-48. http://doi.org/10.1080/03057260608560219

Hennessy, S., Wishart, J., Whitelock, D., Deaney, R., Brawn, R., la Velle, L, .. \& Winterbottom, M. (2007). Pedagogical approaches for technology-integrated science teaching. Computers \& Education, 48, 137-152. http://doi.org/10.1016/j.compedu.2006.02.004

Howe, C. (2014). "If you've seen it before, then you know": Physical evidence and children's trust in testimony. In E. J. Robinson \& S. Einav (Eds.), Trust and skepticism: Children's selective learning from testimony (pp. 151-162). Hove: Psychology Press.

Howe, C., Devine, A., \& Taylor-Tavares, J. (2013). Supporting conceptual change in school science: A possible role for tacit understanding. International Journal of Science Education, 35, 864-883. http://doi.org/10.1080/09500693.2011.585353

Howe, C., Taylor-Tavares, J., \& Devine, A. (2012). Everyday conceptions of object fall: Explicit and tacit understanding in middle childhood. Journal of Experimental Child Psychology, 111, 351-366. http://doi.org/10.1016/j.jecp.2011.09.003

Howe, C., Taylor-Tavares, J., \& Devine, A. (2014). Children's conceptions of physical events: Explicit and tacit understanding of horizontal motion. British Journal of Developmental Psychology, 32, 141-162. http://doi.org/10.1111/bjdp.12026

Howe, C., Taylor-Tavares, J., \& Devine, A. (2016). Recognition as support for reasoning about horizontal motion: A further resource for school science? Research in Science \& Technological Education, 34, 273-289. http://doi.org/10.1080/02635143.2016.1168393

Howitt, C. (2007). Pre-service elementary teachers' perceptions of factors in an holistic methods course influencing their confidence in teaching science. Research in Science Education, 37, 41-58. http://doi.org/10.1007/s11165-006-9015-8

Jaswal, V. K., \& Pérez-Edgar, K (2014). Resolving conflicts between observation and testimony: The role of inhibitory control. In E. J. Robinson \& S. Einav (Eds.), Trust and skepticism: Children's selective learning from testimony (pp. 110-122). Hove: Psychology Press.

Jaswal, V. K. (2010). Believing what you're told: Young children's trust in unexpected testimony about the physical world. Cognitive Psychology, 61, 248-272. http://doi.org/10.1016/j.cogpsych.2010.06.002

Jaswal, V. K. (2013). Biased to believe. In M. R. Banaji \& S. A. Gelman (Eds.), Navigating the social world: What infants, children, and other species can teach us (pp. 241-244). Oxford: Oxford University Press.

Jaswal, V. K., Pérez-Edgar, K., Kondrad, R. L., Palmquist, C. M., Cole, C. A., \& Cole, C. E. (2014). Can’t stop believing: Inhibitory control and resistance to misleading testimony. Developmental Science, 17, 965-976. http://doi.org/10.1111/desc.12187

Jenkins, E., \& Nelson, N. W. (2005). Important but not for me: Students' attitudes towards secondary school science in England. Research in Science \& Technological Education, 23, 41-57. http://doi.org/10.1080/02635140500068435

Kjærnsli, M., \& Lie, S. (2011). Students' preference for science careers: International comparisons based on PISA 2006. International Journal of Science Education, 33, 121-144. http://doi.org/10.1080/09500693.2010.518642

Klaassen, K. (2005). The concept of force as a constitutive element of understanding the world. In K. Boersma, M. Goedhart, O. de Jong, \& H. Eijkelhof (Eds.), Research and the quality of science education (pp. 447-457). Dordrecht: Springer.

Martin, M. O., Mullis, I. V. S., Foy, P., \& Hooper, M. (2016). TIMSS 2015 international results in science. Chestnut Hill, MA: TIMSS \& PIRLS International Study Center.

Murphy, C., \& Beggs, J. (2005). Primary science in the UK: A scoping study. London: Wellcome Trust. 
O'Neill, T., \& Barton, A. (2005). Uncovering student ownership in science learning: The making of a student created mini-documentary. School Science and Mathematics, 105, 292-301. http://doi.org/10.1111/j.1949-8594.2005.tb18130.x

Office for Standards in Education, Children's Services and Skills. (2008). Success in science. Manchester: Ofsted.

Office for Standards in Education, Children's Services and Skills. (2011). Successful science: An evaluation of science education in England 2007-2010. Manchester: Ofsted.

Office for Standards in Education, Children's Services and Skills. (2013). Maintaining curiosity: A survey into science education in schools. Manchester: Ofsted.

Osborne, J., \& Dillon, J. (2008). Science education in Europe: Critical reflections. London: Nuffield Foundation.

Pedretti, E. G., Bencze, L., Hewitt, J., Romkey, L., \& Jivraj, A. (2008). Promoting issues-based STSE perspectives in science teacher education: Problems of identity and ideology. Science \& Education, 17, 941-960. http://doi.org/10.1007/s11191-006-9060-8

Pine, K., Messer, D., \& St John, K. (2001). Children's misconceptions in primary science: a survey of teachers' $\begin{array}{llllll}\text { views. Research in Science \& Technological Education, 19, } & \text { 79-96. }\end{array}$ http://doi.org/10.1080/02635140120046240

Polanyi, M. (1967). The tacit dimension. London: Routledge \& Kegan Paul.

Prensky, M. (2012). From digital natives to digital wisdom. Thousand Oaks: Corwin.

Reeve, J. (2006). Teachers as facilitators: What autonomy-supportive teachers do and why their students benefit. The Elementary School Journal, 106, 225-236. http://doi.org/10.1086/501484

Rice, D. C. (2005). I didn't know oxygen could boil! What preservice and inservice elementary teachers' answers to 'simple' science questions reveals about their subject matter knowledge. International Journal of Science Education, 27, 1059-1082. http://doi.org/10.1080/09500690500069426

Rogers, V. (2012) Early years: Where does science fit in? Primary Science, 123, 28-30.

Roth, G., Assor, A., Kanat-Maymon, Y., \& Kaplan, H. (2007). Autonomous motivation for teaching: How self-determined teaching may lead to self-determined learning. Journal of Educational Psychology, 99, 761-774. http://doi.org/10.1037/0022-0663.99.4.761

Rutten, N., van der Veen, J. T., \& van Joolingen, W. R. (2015). Inquiry-based whole-class teaching with computer simulations in physics. International Journal of Science Education, 37, 1225-1245. http://doi.org/10.1080/09500693.2015.1029033

Said, Z., Summers, R., Abd-El-Khalick, F., \& Wang, S. (2016). Attitudes toward science among grades 3 through 12 Arab students in Qatar: Findings from a cross-sectional national study. International Journal of Science Education, 38, 621-643. http://doi.org/10.1080/09500693.2016.1156184

Shankar, R. (2014). Fundamentals of physics: Mechanics, relativity, and thermodynamics. New Haven, CT: Yale University Press.

Smeets, E. (2005). Does ICT contribute to powerful learning environments in primary education? Computers \& Education, 44, 343-355. http://doi.org/10.1016/j.compedu.2004.04.003

Tamis-LeMonda, C. S., Adolph, K. E., Lobo, S. A., Karasik, L. B., Ishak, S., \& Dimitropoulou, K. A. (2008). When infants take mothers' advice: 18-month-olds integrate perceptual and social information to guide motor action. Developmental Psychology, 44, 734-746. http://doi.org/10.1037/0012-1649.44.3.734

Thoonen, E. E. J., Sleegers, P. J. C., Oort, F. J., Peetsma, T. T. D., \& Geijsel, F. P. (2011). How to improve teaching practices: The role of teacher motivation, organizational factors, and leadership practices. Educational Administration Quarterly, 47, 496-536. http://doi.org/10.1177/0013161X11400185

Tondeur, J., van Braak, J., Sang, G., Voogt, J., Fisser, P., \& Ottenbreit-Leftwich, A. (2012). Preparing pre-service teachers to integrate technology in education: A synthesis of qualitative evidence. Computers \& Education, 59, 134-144. http://doi.org/10.1016/j.compedu.2011.10.009

Trend, R. D. (2001). Deep time framework: A preliminary study of UK primary teachers' conceptions of geological time and perceptions of geoscience. Journal of Research in Science Teaching, 38, 191-221. http://doi.org/10.1002/1098-2736(200102)38:2<191::AID-TEA1003>3.0.CO;2-C 
Tüzün, H., Yılmaz-Soylu, M., Karakuş, T., İnal, Y., \& Kızılkaya, G. (2009). The effects of computer games on primary school students' achievement and motivation in geography learning. Computers \& Education, 52, 68-77. http://doi.org/10.1016/j.compedu.2008.06.008

University of Cambridge (2017). Classroom use and download. Retrieved February 03, 2017, from https://www.educ.cam.ac.uk/research/projects/objectmotion/classroomuse-download/

Van Aalderen-Smeets, S. I., Walma van der Molen, J. H., \& Asma, L. J. F. (2012). Primary teachers' attitudes toward science: A new theoretical framework. Science Education, 96, 158-182. http://doi.org/10.1002/sce.20467

Van Zee, E. H., Iwasyk, M., Kurose, A., Simpson, D., \& Wild, J. (2001). Student and teacher questioning during conversations about science. Journal of Research in Science Teaching, 38, 159-190. http://doi.org/10.1002/1098-2736(200102)38:2<159::AID-TEA1002>3.0.CO;2-J

Vanderlinde, R., \& van Braak, J. (2010). The gap between educational research and practice: Views of teachers, school leaders, intermediaries and researchers. British Educational Research Journal, 36, 299-316. http://doi.org/10.1080/01411920902919257

Wellcome Trust (2014). Primary science: Is it missing out? Recommendations for reviving primary science. London: Wellcome Trust.

White, P. A. (2012). The experience of force: The role of haptic experience of forces in visual perception of object motion and interactions, mental simulation, and motion-related judgments. Psychological Bulletin, 138, 589-615. http://doi.org/10.1037/a0025587

Wiser, M., \& Smith, C. L. (2008). Learning and teaching about matter in grades K-8: When should the atomic-molecular theory be introduced? In S. Vosniadou (Ed.), International handbook of research on conceptual change (pp. 205-239). London: Routledge.

\section{Note}

Note 1. The program used during the present study's interviews and in the studies by Howe and colleagues is available for download at https://www.educ.cam.ac.uk/research/projects/objectmotion/classroomuse-download/

\section{Copyrights}

Copyright for this article is retained by the author(s), with first publication rights granted to the journal.

This is an open-access article distributed under the terms and conditions of the Creative Commons Attribution license (http://creativecommons.org/licenses/by/4.0/). 